\title{
KRIPO - a structure-based pharmacophores approach explains polypharmacological effects
}

\author{
Tina Ritschel ${ }^{1 *}$, Tom JJ Schirris ${ }^{2,3}$, Frans GM Russel ${ }^{2,3}$ \\ From 9th German Conference on Chemoinformatics \\ Fulda, Germany. 10-12 November 2013
}

"The most fruitful basis for the discovery of a new drug is to start with an old one" is a citation from Sir James Black's Nobel laureate (1988).

The background of this statement lies in the fact that most drugs are able to bind to multiple protein targets in the human body, this is known as polypharmacology. This behaviour can lead to unwanted side effects, and innovative research to avoid such adverse properties is of great importance. Paradoxically, polypharmacology can also be used to create new therapeutic approaches, as the protein to which a drug binds causing a side effect in one case, can be the main target for another treatment. Many cases report about the problems and opportunities of polypharmacology.

\footnotetext{
Aims

In order for a drug to bind to multiple targets, the interaction sites of these targets must be similar on a molecular level. Using KRIPO (Key Representation of Interaction in POckets) [1] with specially developed pharmacophore fingerprints, we provide an objective method to accurately describe protein interactions.
}

\section{Results}

KRIPO was used to explain the molecular mechanism of adverse drug effects of HMG-CoA reductase inhibitors, better known as statins. A previously unknown binding site for statins in cytochrome b, the major subunit of mitochondrial complex III of the oxidative phosphorylation system, was predicted by KRIPO.

\footnotetext{
* Correspondence: t.ritschel@umcn.ru.nl

${ }^{1}$ Computational Discovery and Design (CDD) Group at the Centre for Molecular and Biomolecular Informatics (CMBI),UMC Nijmegen, The Netherlands

Full list of author information is available at the end of the article
}

\section{Conclusion}

Combining docking studies with KRIPO and experimental data on complex III inhibition enabled us to explain the molecular details of statin binding to the predicted binding site.

\section{Authors' details}

${ }^{1}$ Computational Discovery and Design (CDD) Group at the Centre for Molecular and Biomolecular Informatics (CMBI),UMC Nijmegen, The Netherlands. ${ }^{2}$ Dept. of Pharmacology and Toxicology, UMC, Nijmegen, the Netherlands. ${ }^{3}$ Centre for Systems Biology and Bioenergetics, UMC, Nijmegen, the Netherlands.

\section{Published: 11 March 2014}

\section{Reference}

1. Wood DJ, de Vlieg J, Wagener M, Ritschel T: Pharmacophore FingerprintBased Approach to Binding Site Subpocket Similarity and Its Application to Bioisostere Replacement. J Chem Inf Model 2012, 52:2031-2043.

\section{doi:10.1186/1758-2946-6-S1-O26}

Cite this article as: Ritschel et al:: KRIPO - a structure-based

pharmacophores approach explains polypharmacological effects. Journal of Cheminformatics 2014 6(Suppl 1):O26.

\section{Publish with ChemistryCentral and every scientist can read your work free of charge \\ "Open access provides opportunities to our colleagues in other parts of the globe, by allowing anyone to view the content free of charge." \\ W. Jeffery Hurst, The Hershey Company. \\ - available free of charge to the entire scientific community \\ - peer reviewed and published immediately upon acceptance \\ - cited in PubMed and archived on PubMed Central \\ - yours - you keep the copyright \\ Submit your manuscript here: \\ http://www.chemistrycentral.com/manuscript/}

